\title{
Holocene thermal optimal and climate variability of East Asian monsoon inferred from forest reconstruction of a subalpine pollen sequence, Taiwan
}

\author{
P.M. Liew ${ }^{\mathrm{a}, *}$, C.Y. Lee ${ }^{\mathrm{a}, 1}$, C.M. Kuo ${ }^{\mathrm{b}, 2}$ \\ a Department of Geosciences, National Taiwan University, 1, Sec. 4, Roosevelt Rd. Taipei, Taiwan, R.O.C. \\ ${ }^{\mathrm{b}}$ Chinese Petroleum Coperation, 3, Sungren Rd, Shinyi Chiu, Taipei 10110, Taiwan, R.O.C.
}

Received 19 December 2005; received in revised form 13 July 2006; accepted 3 August 2006

Available online 25 September 2006

Editor: G. D. Price

\begin{abstract}
The East Asian monsoon Holocene optimal period has been debated both about duration and whether conditions were a maximum in thermal conditions or in precipitation. In this study we show Holocene climate variability inferred by a forest reconstruction of a subalpine pollen sequence from peat bog deposits in central Taiwan, based on modern analogues of various altitudinal biomes in the region. A warmer interval occurred between 8 and 4 ka BP (calibrated ${ }^{14} \mathrm{C}$ years) when the subtropical forests were more extensive. The Holocene thermal optimum is represented by an altitudinal tropical forest at $6.1-5.9 \mathrm{ka}$ BP and $6.9 \mathrm{ka} \mathrm{BP}$ and only the latter was accompanied by wet conditions, indicating decoupling of thermal and precipitation mechanism in the middle Holocene. Abrupt and relative severe cold phases, shown by biome changes, occurred at about $11.2-11.0 \mathrm{ka}$ BP; $7.5 \mathrm{ka}$ BP; $7.2 \mathrm{ka} \mathrm{BP;} 7.1 \mathrm{ka} \mathrm{BP;} 5.2 \mathrm{ka} \mathrm{BP}, 5.0 \mathrm{ka} \mathrm{BP}$ and $4.9 \mathrm{ka} \mathrm{BP}$. A spectral analysis of pollen of a relatively cold taxon - Salix, reveals that the time series is dominated by a $1500 \mathrm{yr}$ periodicity and similar to the cold cycle reported in the marine records of Indian and western Pacific Oceans. The cold-warm conditions inferred by the change of forests show close relationship to solar energy in comparison with the production rate of Be-10.
\end{abstract}

(C) 2006 Elsevier B.V. All rights reserved.

Keywords: Holocene thermal optimal; East Asian monsoon; forest reconstruction; abrupt change

\footnotetext{
* Corresponding author. Tel.: +886 2 33662932; fax: +886 2 23636095

E-mail addresses: liewpm@ntu.edu.tw (P.M. Liew), d93224006@ntu.edu.tw (C.Y. Lee),142379@cpc.com.tw (C.M. Kuo).

${ }^{1}$ Tel.: +886 2 33662932; fax: +886223636095.

${ }^{2}$ Tel.: +8862 87259622 .
}

\section{Introduction}

The Holocene thermal optimum, at about $6 \mathrm{ka}$, is a period when wide areas of high latitudes were warmer, and the northern subtropical regions were wetter than at present [1]. A summer thermal optimum at 6 ka occurs over a wide area of northern Europe [2]. In the East Asian monsoon area, there is little evidence showing a corresponding thermal environment although a maximum precipitation is suggested for the period [3] and 
whether the optimum is synchronous has often been debated in China [3-5]. In contrast, a relatively drier middle Holocene has been indicated in southern [6] and northern China [7]. Additional high resolution records are necessary for understanding the Holocene variations in eastern Asia.

Millennial to centennial time-scale abrupt climate change during the Holocene, based on ice cores, marine and lake and bog sediments and stalagmites exist [814]. A major question remains on whether these changes are hemispheric or global, and what the forcing mechanism might be. Holocene records of abrupt change in Asian monsoon circulation are based mostly on marine sediments. Cycles of cold events, similar to the ice rafted detritus (IRD) event in the north Atlantic during the Holocene $[12,13]$ are reported in peat bog sediments [14] and marine sediments of the Indian Ocean and Sulu Sea [15-17]. High resolution stalagmite records of the Hulu Cave [10] and that of the Dongge Cave [11] in China show that East Asian monsoon changes are in concert with events in Greenland, while Holocene precipitation change may result from orbitally induced insolation, solar output and coupled oceanic/ atmospheric circulation. These records help improve our understanding of East Asian monsoon circulation, especially with respect to precipitation.

The relative magnitude of climatic changes (in both temperature and precipitation) in the East Asian monsoon areas, as well as that of sea surface temperatures in the North Atlantic is important for discriminating whether external forcing, such as solar output, or internal forcing such as oscillations in the North Atlantic northward heat transport, are the drivers of both the North Atlantic cycles and variations of monsoon intensity [18]. We present the result of a forest reconstruction, of the Holocene age from a high resolution pollen sequence in Toushe Peat Bog, in central Taiwan. We base our analysis on the biomization technique $[19,20]$. We use this as a basis to reveal Holocene climate variations, as well as the relative magnitude of climate change of the East Asian monsoon region, as shown by vegetation response.

\section{Location, vegetation and pollen record}

The Toushe Peat Bog $\left(23^{\circ} 49^{\prime \prime} \mathrm{N}, 120^{\circ} 53^{\prime} \mathrm{E}\right)$, with an area of $1.75 \mathrm{~km}^{2}$ and an altitude of $650 \mathrm{~m}$, is located among a series of possibly pull apart basins of the main NE-SW trending faults within the backbone of central Taiwan (Fig. 1). In the mountainous central Taiwan area, there exists the following altitudinal biomes or forest zones [21,22] with an annual temperature range from tropical to subalpine: tropical evergreen forest (altitude
$<500$ m, Ficus-Machilus Zone); subtropical evergreen forest (500-1500 m, Machilus-Castanopsis Zone); warm-temperate evergreen forest (1500-2000 m, Lower Quercus Zone); temperate broadleaved and conifer mixed forest (2000-2500 m, Upper Quercus Zone); cool temperate conifer forest (2500-3100 m, Tsuga-Picea Zone); cold temperate conifer forest $(3100-3600 \mathrm{~m}$, Abies Zone) and alpine vegetation zone (>3600 m, Juniperus-Rhododendron scrub). The Toushe Basin is surrounded by a subtropical evergreen broadleaved forest i.e. the Castanopsis-Machilus Zone. The site was previously a lake, becoming a peat bog by the early last glacial and dried out at about $1.7 \mathrm{ka}$ BP. The annual temperature and precipitation, extrapolated from a nearby meteorological station, Sun Moon Lake, are $21.2{ }^{\circ} \mathrm{C}$ and $2341 \mathrm{~mm}$ and reveals the primary rainy season is from May to September. A 39.6 m-long core covering sediments since early last glacial was obtained in 1999 in Toushe, of which the upper $30 \mathrm{~m}$ are mainly peat. Pollen record has been published [23-25].

\section{Methods}

\subsection{Chronology}

There are thirteen ${ }^{14} \mathrm{C}$ dates in peaty sediments of Holocene age, based on 11 conventional and 2 AMS dates (Table 1). The former were measured at the ${ }^{14} \mathrm{C}$ Laboratory at National Taiwan University and the latter at laboratory of the Institute of Geological and Nuclear Sciences, New Zealand. Calibrated radiocarbon ages [26] are used for the following description and the age of each depth is extrapolated from the two nearest dates. The resolution is about $105-120 \mathrm{yr}$ during the Holocene where the sedimentation rate is relatively stable at about $86 \mathrm{~cm} /$ ka (Fig. 1).

\subsection{Biomization of modern forests and Holocene sequence of central Taiwan}

This study offers results of a forest reconstruction of the Holocene pollen sequence using the biomization technique [25] so as to indicate the relative magnitude of climate change. The biomization method was originally developed in Europe and has been applied in China $[19,20]$. The method assigns plant functional types (PFTs) to help classify plant ecology for treating pollen taxa. Certain basic physiognomic characteristics appear in functionaltype classifications, such as arboreal/non arboreal, leafform (broad/needle), phenology (evergreen/summer green) and criteria controlled by climate (warm/cold, dry/wet, etc.). We then combined the PFTs into altitudinal 


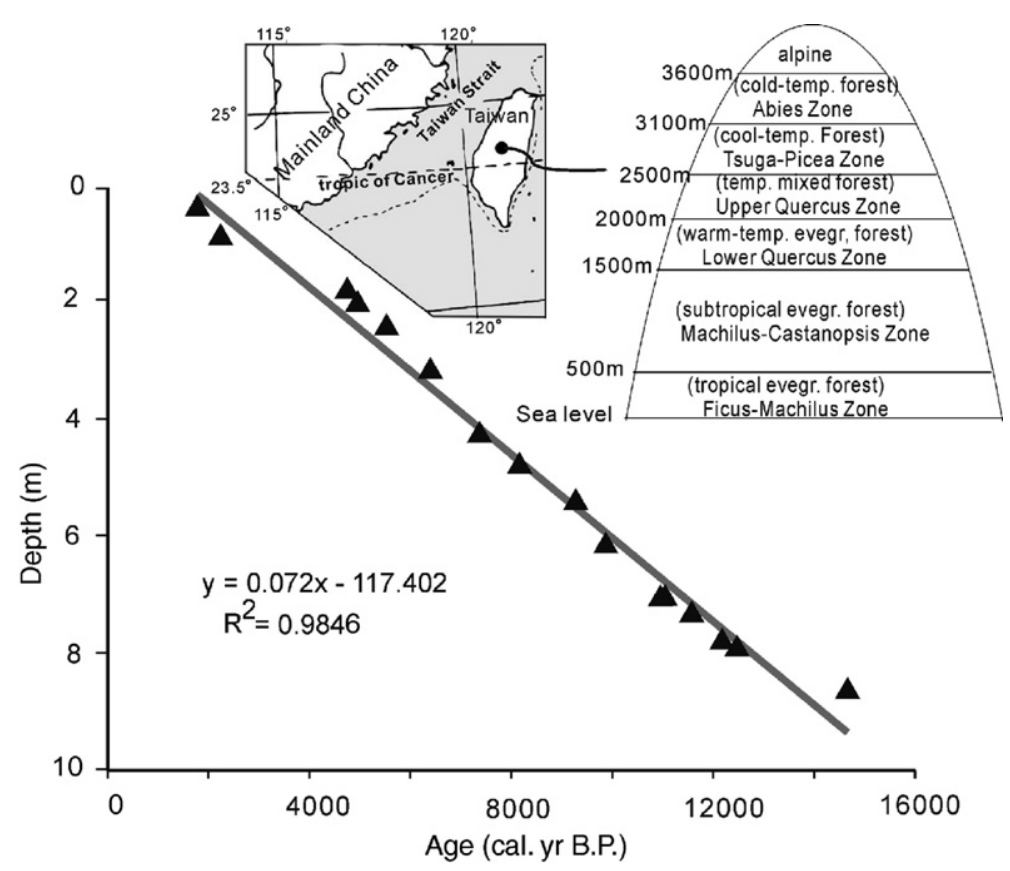

Fig. 1. Study site, depth versus age of the Toushe core and the regional altitudinal forest zones.

vegetation (the biome) [27] defined by these known criteria largely controlled by climate.

In this paper, plant functional types (PFTs) and biomes used in the Holocene forest reconstruction or biomization were first tested in modern forests of the Salixian area, a mountain range $30 \mathrm{~km}$ southeast of the Toushe core. Surface pollen assemblages of 16 sites in the Salixian area between altitudes 700 and $2800 \mathrm{~m}$ were simulated. In the simulation of modern forests [25], we modified the previous work of $\mathrm{Yu}$ et al. [20] and name PFTs (supplement Tab. 1) and biomes (supplement Tab. 2) by the aforementioned altitudinal zones of central Taiwan with reference to the altitudinal vegetation and ecological data available. Thus, the tropical evergreen forest corresponds to the Ficus-Machilus Zone $\left(<500 \mathrm{~m} ; .23{ }^{\circ} \mathrm{C}\right.$ annual temperature) and subtropical evergreen forest to Machilus-Castanopsis Zone (500-1500 m; $\left.17-23{ }^{\circ} \mathrm{C}\right)$; warm-temperate evergreen forest to the Lower Quercus Zone (1500$2000 \mathrm{~m} ; 14-17^{\circ} \mathrm{C}$ ) and temperate evergreen, deciduous and conifer mixed forest (comprised of the montane evergreen forest, montane mixed coniferous forest; montane deciduous forest) to the Upper Quercus Zone (2000-2500 m; $11-14{ }^{\circ} \mathrm{C}$ ); and cool temperate coniferous forest to Tsuga-Picea Zone (2500-3100 m; 8$11{ }^{\circ} \mathrm{C}$ ). The result of the simulations (Fig. 2) show a good reconstruction of modern forests of which 15 of the total the 16 sites of the natural forests of Salixian are correctly reconstructed. Only one sample in the temperate forest (altitude $2150 \mathrm{~m}$ ) was incorrectly reconstructed as a warm-temperate forest with regards to two solutions of biome affinity are possible for those sites at or around an ecotone boundary i.e. $1450 \mathrm{~m} ; 1530 \mathrm{~m}$, $1500 \mathrm{~m}$ and $2000 \mathrm{~m}$.

Table 1

Ages versus depths of the studied core

\begin{tabular}{lccl}
\hline $\begin{array}{l}\text { Depth } \\
(\mathrm{cm})\end{array}$ & $\begin{array}{l}{ }^{14} \mathrm{C} \text { age } \\
\text { (yr BP) }\end{array}$ & $\begin{array}{l}\text { Calibrated }{ }^{14} \mathrm{C} \\
\text { age }(\mathrm{yr})\end{array}$ & $\begin{array}{l}\text { Lab no or }{ }^{18} \mathrm{O} \text { age } \\
\text { equivalent }\end{array}$ \\
\hline $30-40$ & $1840 \pm 50$ & $1711-1857$ & NTU-1883 \\
$80-90$ & $2230 \pm 50$ & $2156-2326$ & NTU-1862 \\
$172-182$ & $4230 \pm 50$ & $4650-4851$ & NTU-1873 \\
$190-210$ & $4410 \pm 40$ & $4873-5042$ & NTU-2061 \\
$235-245$ & $4800 \pm 50$ & $5473-5594$ & NTU-2062 \\
$310-320$ & $5640 \pm 60$ & $6314-6487$ & NTU-1856 \\
$420-430$ & $6480 \pm 60$ & $7319-7430$ & NTU-1865 \\
$473-483$ & $7370 \pm 60$ & $8041-8289$ & NTU-1928 \\
$535-545$ & $8270 \pm 70$ & $9131-9417$ & NTU-1934 \\
$610-620$ & $8780 \pm 60$ & $9633-10,105$ & NTU-1847 \\
$705-707$ & $9600 \pm 130$ & $10,750-11,157$ & NZ-4089 \\
$700-710$ & $9720 \pm 60$ & $10,892-11,201$ & NTU-1852 \\
$733-734$ & $10,059 \pm 87$ & $11,263-11,885$ & NZA-6258 \\
$780-781$ & $10,309 \pm 89$ & $11,768-12,582$ & NZA-6259 \\
$787-796$ & $10,450 \pm 70$ & $12,158-12,786$ & NTU-1944 \\
$861-870$ & $12,100 \pm 90$ & $14,380-14,942$ & NTU-1988 \\
$930-941$ & $12,350 \pm 90$ & $14,116-15,053$ & NTU-1996 \\
$1008-1019$ & $13,700 \pm 100$ & $16,188-16,701$ & NTU-3006 \\
\hline
\end{tabular}

Radiocarbon yr were converted to calendar yr. [45,46]. 


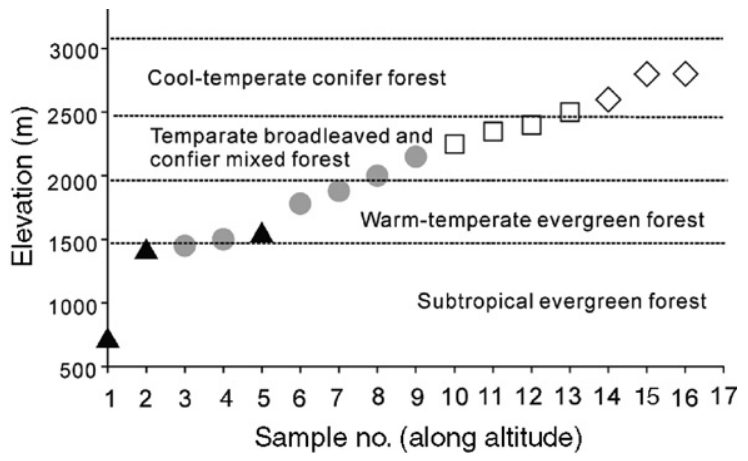

Fig. 2. Simulated vegetation based on the surface pollen data of Salixian natural forests using the biomization technique, central Taiwan. The dash lines show the lower boundaries of actual vegetation in order to compare with the simulated one. Codes for biomization simulated vegetation are: $\boldsymbol{\Delta}$ subtropical evergreen forest; warmtemperate evergreen forest; $\square$ temperate broadleaved and conifer mixed forest; $\diamond$ cool-temperate conifer forest.

Following the modern altitudinal forests which were well simulated ( 15 of the total the 16 sites of natural forests were correctly reconstructed), we commence the simulation of the Holocene sequence of Toushe.

\section{Results}

\subsection{Results of the Holocene forest reconstruction}

Fig. 3 shows the simplified Holocene pollen diagram with the percentage of each pollen genus based on total pollen, whereas that of the spores is based upon the sum of pollen and spores. In contrast to the deciduous broadleaved forest of Alnus, shown during most of the last glacial, the Holocene is characterized by an increase of Castanopsis type pollen — the major element of subtropical to warm-temperate evergreen forests, and the remarkable rise of pteridophyte spores which indicates an increase of temperature and humidity [24]. We adopted the PFTs (supplement Tab. 1) and biomes (supplement Tab. 2) from the modern forest simulation for the Salixian to the Holocene forest reconstruction of the Toushe core. Results from the biomization in the fossil sequence shows an altitudinal shift of forests during Holocene (Figs. 3, 4a). The righthand column of Fig. 3 indicates the result of biomization which shows the Holocene forests along the 1st axis of detrended correspondence analysis (DCA by the Tilia Program) [28] of pollen taxa with a percentage $>2 \%$; whereas the last column shows the affinity score of each forest (biome) during the Holocene. The same result is also plotted along the time axis in Fig. $4 \mathrm{a}$.
The frequency of forest shifts may relate to the spacing of altitudinal biomes and their range of favorable habitats [29]. A Holocene vegetation shift probably indicates that the site in relation to major ecotones renders the surrounding vegetation potentially sensitive to relatively small environmental changes. The area is presently surrounded by a subtropical evergreen forest, and was dominated by a subtropical evergreen forest $(500-1500 \mathrm{~m})$ and warmtemperate evergreen forest (1500-2000 m) during the Holocene, except when abrupt climate change occurred. This terrestrial pollen record (Fig. 3) provides the response function of relative magnitude of abrupt climate changes by simulated altitudinal vegetation; and the acceptable dates due to its peaty sediments which exclude a reservoir effect of ${ }^{14} \mathrm{C}$ date when compared with long marine record.

The forest types present during the Holocene are plotted on the 1st axis of detrended correspondence analysis (DCA) of the pollen assemblage and indicate the component gradient in Fig. 4a [28]. Subtropical and warm-temperate evergreen forests dominated during the Holocene while temperate broadleaved and conifer mixed forest occurred during the last glacial period. Subtropical conditions after the late glacial are indicated from forest reconstruction at $11.5 \mathrm{ka} \mathrm{BP}$ (depth $7.28 \mathrm{~m}$ ). Subsequently, cold conditions (temperate forest) prevailed around $11.2-11.0 \mathrm{ka}$ BP yet again. Still later, $10.8 \mathrm{ka} \mathrm{BP}$, warm-temperate and subtropical forests prevailed, similar to the age of boundary late glacial/ Holocene i.e.10,750 ka BP as inferred from the Dunde Ice core [30]. An exception occurs in the following ages: cold events are represented by temperate forest type at about 7.5 ka BP; 7.2 ka BP; 7.1 ka BP; 5.2 ka BP, 5.0 ka $\mathrm{BP}$ and $4.9 \mathrm{ka}$ BP while warm events represented by tropical forest type (red dot) at 6.9 ka BP and 6.1-5.9 ka BP. Subtropical vegetation types prevailed between 8 and $4 \mathrm{ka} \mathrm{BP}$ and warm-temperate vegetation types prevailed in the early Holocene. Pollen assemblages of samples with equal affinity score of subtropical evergreen forest and warm-temperate evergreen forest were common during the early Holocene (Fig. 3). However, they should be assigned to warm-temperate forest rather than subtropical forest according to the rules used for selecting the biome which composed the least PFTs. The difference between these two forest types is relatively small due to the fact that the main pollen types of forests of the zone are the Fagaceae - especially Castanopsis-type pollen. Castanopsis is the main element of subtropical to warm-temperate forests. The same idea was invoked by Tsukada [31], since he clustered forest from altitudes $500 \mathrm{~m}$ to $1800 \mathrm{~m}$ as "warm-temperate forest". 


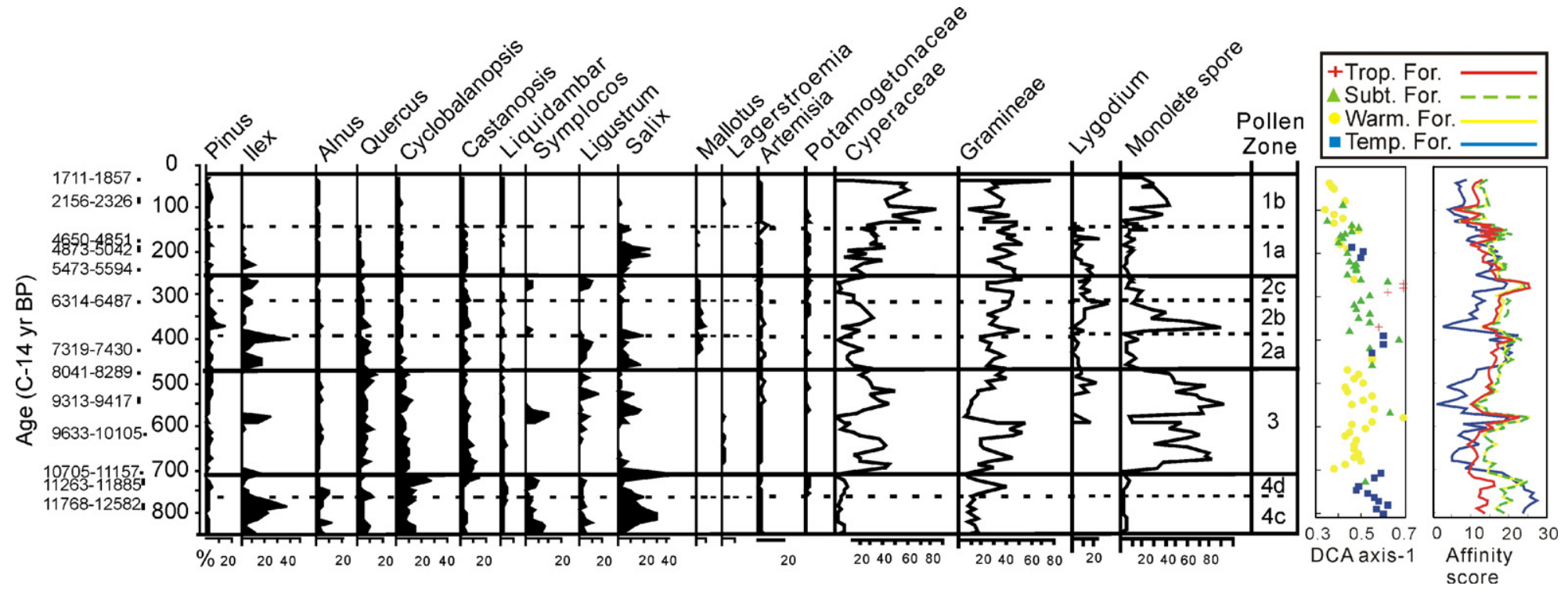

Fig. 3. Simplified pollen diagram of Toushe core, percentage values for selected taxa are shown along with the result of reconstructed forest on the 1st axis of detrended correspondence analysis (DCA) and the affinity scores of reconstructed forests in the last column. Percentage of each pollen taxon is based on total pollen while percentage of each spore taxon is based on sum of pollen and spores. The Holocene is characterized by remarkable increase of pteridophytes and the subtropical taxa such as Castanopsis. In the affinity scores of reconstructed Holocene forests, red color represents tropical evergreen forest; green represents subtropical evergreen forest; yellow represents warm-temperate evergreen forest and blue represents temperate broadleaved and conifer mixed forest. 


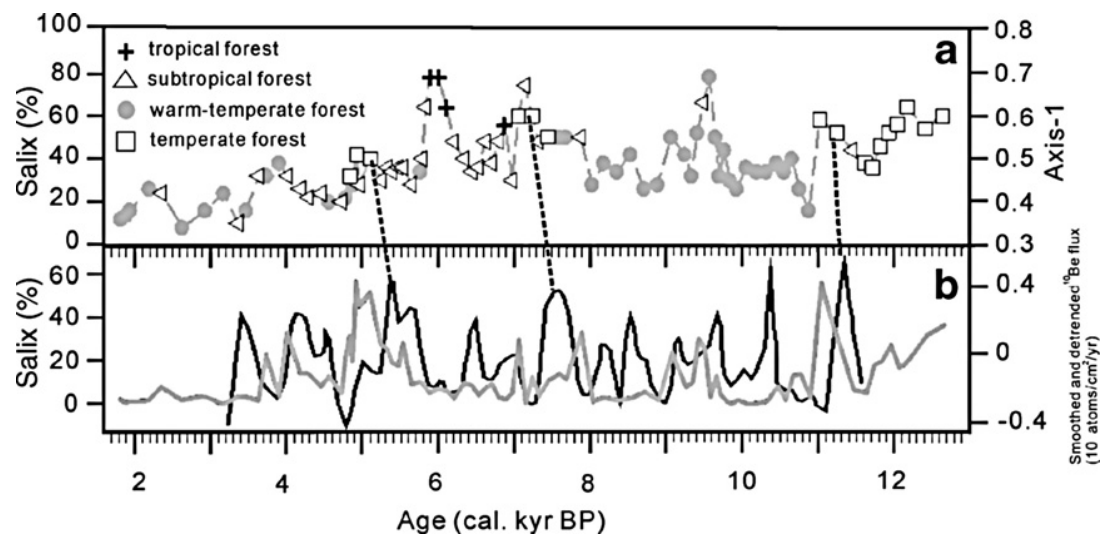

Fig. 4. a: Result of forest reconstruction along time axis of Toushe pollen sequence is shown on the DCA 1st axis; b: Be -10 curve ${ }^{13}$ in solid line and percentage of Salix, a relatively cold/dry element, among woody taxa shown by grey line; most of Salix peaks lag to that of Be-10 curve about hundreds of years but both dominated by a $1500 \mathrm{yr}$ periodicity; dotted lines between Figs. a and b show the possible connection of peaks of Be-10 curve and major cold events indicated by forest shift.

\subsection{The Holocene climate optimum}

The nature of the Holocene optimum has been debated in the East Asian monsoon area both for its duration and on the conditions of maximum precipitation or temperature. A relatively warm and wet period between 10 and $6 \mathrm{ka}$ BP was proposed in both northern and southern China, from studies of peaty sediments [6,32]. A middle Holocene warm-humid from 9000 to $4000{ }^{14} \mathrm{C}$ yr BP is inferred from lacustrine and eolian deposits in the Mongolian Plateau [33] and a warmer phase between 7 and $5.5 \mathrm{ka} \mathrm{BP}$ in the desert/loess transition of north central China has also been reported [34]. According to our present study, a warmer interval represented by abundant subtropical forest, exists between 8 and $4 \mathrm{ka}$ BP and thermal optima are represented by tropical forest at $6.9 \mathrm{ka}$
BP and 6.1-5.9 ka BP. In the South China Sea, a high sea surface temperature between 6.8 and $5.0 \mathrm{ka} \mathrm{BP}$ was reported from a study of mean $\mathrm{Sr} / \mathrm{Ca}-\mathrm{SST}$ of coral [35]. Although higher humidity of the Holocene optimum has been proposed in previous studies [3], our record indicates that the period between 8 and $4.5 \mathrm{ka} \mathrm{BP}$ is relatively low in humidity compared with the higher humidity indicated by spores in the early Holocene, except between 6-7 ka BP when the amount of spores is still significant and specifically a short wet period may exist at 6.9-6.8 ka BP (Fig. 5b). A relatively dry phase in the middle Holocene is probably related to the migration of the summer monsoon front to northern China [36]. Abrupt cold warm fluctuations shown by the shift of forest type occurs in the warm period from 8 to 4 ka BP. Prominent and abrupt cold phases are discussed below. A climate

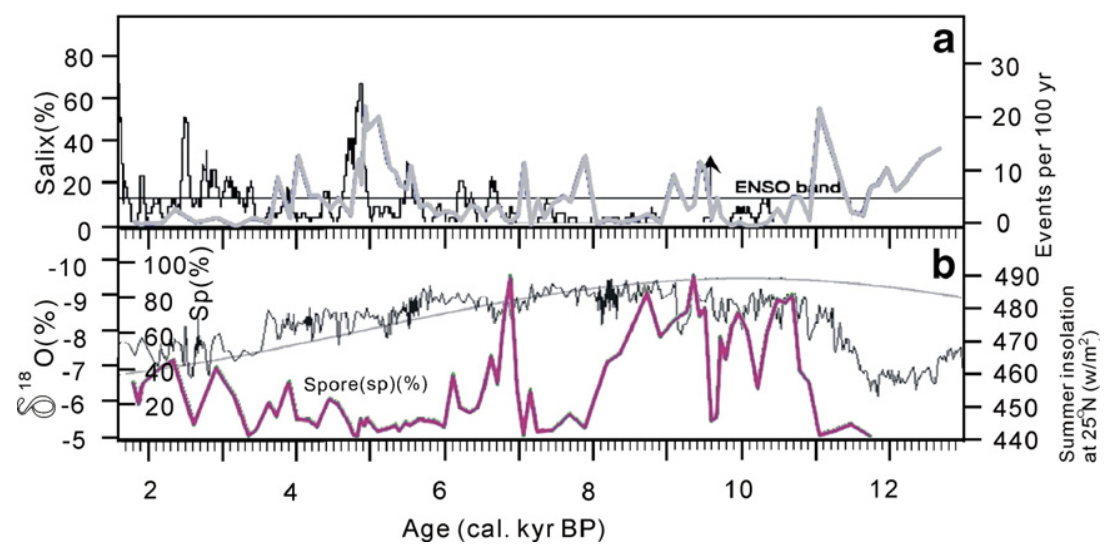

Fig. 5. a: Salix percentage of Toushe Holocene sequence and the ENSO frequency in Ecuador ${ }^{42}$, note that frequent ENSO is in phase with low Salix value (warmer period) prior to $7.0 \mathrm{ka} \mathrm{BP}$. b: The lower curve is the spore percentage which representing humid conditions. Relatively low value occurred between 8 and $4.5 \mathrm{ka} \mathrm{BP}$. The upper curve for comparison is the $\delta^{18} \mathrm{O}$ value of stalagmite of Dongge Cave with resolution $19 \mathrm{yr}$, China ${ }^{11}$. 
change at $4 \mathrm{ka} \mathrm{BP}$, is thought to be coincident with the collapse of Neolithic culture in China [36]. However, the ending of a long warm period from 8 to $4 \mathrm{ka}$ BP may have had a significant effect on ancient cultures, although the cold event at $4 \mathrm{ka} \mathrm{BP}$ is not the severest one in the middle Holocene, as shown in this study.

The high humidity intervals inferred by percentages of spores (Fig. 5b), occur at 10.6-10.3 ka BP; 10-9.7 ka BP; 9.5-8.5 ka BP and 6.9-6.8 ka BP. Only the thermal optimum at 6.9-6.8 ka BP (Fig. 4a) accompanied by a high spore peak which probably indicates a precipitation event. This phenomenon shows that thermal and humidity conditions may decouple during the thermal optimal 6-7 ka BP. The relatively drier record of the middle Holocene is different from the record of the Dongge Cave where high humidity conditions last from the early to middle Holocene. This difference is possibly due to the integrated influence of Indian and East Asian monsoons in the Dongge Cave record.

\subsection{Time series of the Holocene Salix series}

Salix, presently a relatively cold dry taxon in Toushe, (and seven of the total of nine Salix species in Taiwan are distributed in mountainous areas higher than $1600 \mathrm{~m}$ ) grows in open areas of mountains above $1600 \mathrm{~m}$ near the studied site [37]. Salix pollen percentage values peak during Holocene (Fig. 4b) as follows: 11.2-11.0 ka BP; 9.4 ka BP; 8.9 ka BP; 7.1 ka BP; 7.2 ka BP; 7.5 ka BP; 5.2 ka BP; 5.0 ka BP; 4.0 ka BP; 3.7 ka BP. The higher peak values usually coincide with the cold events represented by temperate forest. The high-Salix values at 11.2 ka BP; 11.0 ka BP; 9.4 ka BP; 4.0 ka BP and $3.7 \mathrm{ka}$ $\mathrm{BP}$ correspond to the punctuated Holocene positive $\delta^{18} \mathrm{O}$ events in the Dongge Cave if put within dating limits in the brackets. Both thermal and precipitation effects possibly caused these events. Cold events represented by strong winter monsoon at intervals between 7.5-7.0 ka BP are also recognized by a $\mathrm{Sr} / \mathrm{Ca}$ study of corals of the South China Sea [38] and the more negative signal of $\delta^{18} \mathrm{O}$ of Dunde Ice core at this time [30]. Cold events between 7.2 and $7.8 \mathrm{ka} \mathrm{BP}$ are also indicated in the records from Levant (Middle East) and East Africa [39]. 5.2 ka BP and $4 \mathrm{ka} \mathrm{BP}$ cold events have been reported in ice core studies from Tropical Africa [40]. These events thus seem to be global with the event at $5.2 \mathrm{ka} \mathrm{BP}$ stronger than that of the $4 \mathrm{ka}$ $\mathrm{BP}$, as shown by vegetation response in our study.

A spectral analysis of Salix pollen percentages among woody taxa indicates that the time series of the Holocene sequence is dominated by the $1500 \mathrm{yr}$ periodicity (Fig. 6). This is similar to the cold cycle of $1500 \mathrm{yr}$ in the Indian Ocean $[15,41]$ and Sulu Sea [16]; the Holocene IRD of the

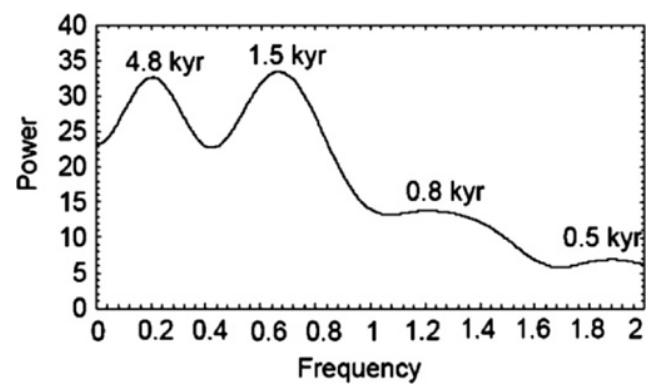

Fig. 6. Time series of Salix percentage dominated by the $1500 \mathrm{yr}$ periodicity.

north Atlantic [12,13], the ENSO cyclicity of the Holocene in southern Ecuador [42] and that of the last glacial in Australia [43]. In Australia the millennial-scale dry periods during the last glacial, probably indicate periods of frequent El Nino events (summer precipitation declines in El Nino years) and these dry periods are possibly correlated to the $\mathrm{D} / \mathrm{O}$ events, millennial warm events in the North Atlantic climate record. If this relationship extends to the Holocene, periods of frequent El Nino events will recur as millennial scale warm events in the North Atlantic or Northern Hemisphere. The Holocene ENSO frequency of Ecuador (Fig. 5a) compares with our Salix percentage curve, thus the ENSO is in phase with low Salix percentage (warmer event) before $7.0 \mathrm{ka} \mathrm{BP}$, but not thereafter. As shown in this study, $7.0 \mathrm{ka} \mathrm{BP}$ is a turning point of abrupt change from cold (at $7.1 \mathrm{ka} \mathrm{BP}$ and before) to a remarkable warm phase (at $6.9 \mathrm{ka} \mathrm{BP}$ and middle Holocene thermal optimal) and from relatively dry (8-7 ka BP) to abruptly wet conditions at $6.9 \mathrm{ka} \mathrm{BP}$ (Fig. 5a and b) which suggests significant changes in ocean-atmosphere circulation patterns.

\section{The comparison between climatic variations and production rate of $\mathrm{Be}-10$}

The record of sequential Holocene forest change reflects the relative magnitude of climatic change. We here compare climatic variations with the production rate of nuclide Be-10 [12,13] within ice cores to further discussion of one of the possible significant forcing agents.

The curve of smoothed (70 yr) detrended nuclide record of Be-10 and curve of Salix percentage among tree and shrubs are shown in Fig. $4 \mathrm{~b}$, both show their time series dominated by the $1500 \mathrm{yr}$ periodicity. Given the response of vegetation to abrupt climate change with a lag of 0-(150)200 yr [44], the prominent cold and dry phases (temperate forest) revealed in the vegetation i.e. 11.211.0 ka BP; 7.5 ka BP; 7.2 ka BP; 7.1 ka BP; 5.2 ka BP; $5.0 \mathrm{ka} \mathrm{BP}$ and $4.9 \mathrm{ka} \mathrm{BP}$, coincide with the most broad, 
Table 2

Comparison among events of Be-10 peaks, shifting forests ${ }_{\star}$ relatively prominent which excluding those shifts between subtropical forest and warm-temperate forest) and Salix peaks

\begin{tabular}{|c|c|c|}
\hline High Be-10 peak & Change to colder forest type & Existence of Salix peak \\
\hline $11.2 \mathrm{ka} \mathrm{BP}$ & * $11.2-11.0 \mathrm{ka} \mathrm{BP}$ from subtr. to temp. & $11.2-11.0 \mathrm{ka} \mathrm{BP}$ \\
\hline $10.4 \mathrm{ka} \mathrm{BP}$ & Absent & Absent \\
\hline $9.6 \mathrm{ka} \mathrm{BP}$ & $9.4 \mathrm{ka} \mathrm{BP}$ from subtr. to warm-temp. & $9.4 \mathrm{ka} \mathrm{BP}$ \\
\hline 7.6-7.4 ka BP & * $7.5 ; 7.2-7.1 \mathrm{ka} \mathrm{BP}$ from subtr. to temp. & $7.5,7.2,7.1 \mathrm{ka} \mathrm{BP}$ \\
\hline $5.6-5.3 \mathrm{ka} \mathrm{BP}$ & * 5.2; $5.0 \mathrm{ka} \mathrm{BP}$ from subtr. to temp. & $5.2 ; 5.0,4.9 \mathrm{ka} \mathrm{BP}$ \\
\hline $4.2 \mathrm{ka} \mathrm{BP}$ & 4.0 ka BP from subtr. to warm-temp. & $4.0 \mathrm{ka} \mathrm{BP}$ \\
\hline $3.5 \mathrm{ka} \mathrm{BP}$ & $3.5 \mathrm{ka} \mathrm{BP}$ from subtr. to warm-temp. & Absent \\
\hline Low Be-10 peak & Change to warmer vergetation type or with high spore value & \\
\hline $11-10.4 \mathrm{ka} \mathrm{BP}$ & * 10.8 ; temp to warm-temp. & \\
\hline $10.2-9.7 \mathrm{ka} \mathrm{BP}$ & $10.0-9.7 \mathrm{ka} \mathrm{BP}$ peak of spore; $9.5 \mathrm{ka} \mathrm{BP}$ from warm-temp to subtr. & \\
\hline $9.1-8.8 \mathrm{ka} \mathrm{BP}$ & $9.5-8.5 \mathrm{ka}$ BP peak of spore & \\
\hline $7.9 \mathrm{ka} \mathrm{BP}$ & $7.9 \mathrm{ka} \mathrm{BP}$ from warm-temp. to subtr. & \\
\hline $7.1-7.0 \mathrm{ka} \mathrm{BP}$ & * 6.9-6.8 ka BP from subtr. to trop. & \\
\hline $6.2-5.8 \mathrm{ka} \mathrm{BP}$ & * 6.1-5.9 ka BP from subtr. to trop. & \\
\hline $4.8-4.7 \mathrm{ka} \mathrm{BP}$ & 4.8-4.7. ka BP from warm-temp. to subtr. & \\
\hline $3.9 \mathrm{ka} \mathrm{BP}$ & $3.9 \mathrm{ka}$ BP from warm-temp. to subtr. & \\
\hline
\end{tabular}

and/or prominent peaks (the dotted line between Fig. 4a and $b$ ) in the curves of the smoothed detrended nuclide record of high Be-10. The onset of the continuous Holocene warm period (10.8 ka BP) and the middle Holocene thermal optimum (6.1-5.9 ka BP) correspond to the prominent trough of low Be-10. Sudden cold and warm phases denoted by changes of forest type (Fig. 4a) are compared with curve of Be-10 (Table 2). Climate changes with higher magnitude shown by forest changes are likely to relate with higher or wider peaks of Be-10. A close relationship between events of vegetation change and Be10 values appear, except where short events corresponding to the relatively narrow peaks of high $\mathrm{Be}-10$ curve at $8.5 \mathrm{ka}$ $\mathrm{BP}$ and $6.4 \mathrm{ka}$ BP and low Be-10 curve at $8.3 \mathrm{ka}$ BP (Fig. 4b). These are possibly due to the resolution of samples missing the still short events or the response range of forests. However, the warmer interval at about 5.9$6.1 \mathrm{ka} \mathrm{BP}$ coincides with the broader but not the lowest trough of Be-10 curve and the warm but punctuated wet event at $6.9 \mathrm{ka} \mathrm{BP}$, probably indicate the orbital forcing or ocean-atmosphere circulation changes superposed on solar variability that influences abrupt climate change.

\section{Conclusion}

1. The climatic events inferred from altitudinal forest shifts during the Holocene in central Taiwan, based on a biomization technique show that the warmer Holocene period is between 8 and $4 \mathrm{ka}$ BP. Thermal optima occurred at 6.1-5.9 ka BP and 6.9 ka BP and the latter was accompanied by wet conditions. Apart from the time between 7 and 6 ka BP humidity is relatively low between 8 and 4.5 ka BP compared with the early Holocene as inferred from changes of percentage values of fern spores.

2. Prominent and abrupt cold phases (represented by temperate forest expansions) occurred at $11.2-11.0 \mathrm{ka}$ BP; 7.5 ka BP; 7.2 ka BP; 7.1 ka BP; 5.2 ka BP; 5.0 ka $\mathrm{BP}$ and $4.9 \mathrm{ka} \mathrm{BP}$. In contrast, the cold event at $4 \mathrm{ka} \mathrm{BP}$ does not appear to be the most severe during middle Holocene. The diminishing of Neolithic culture in northern China possibly resulted from the ending of a long warmer period 8-4 ka BP in China rather than a severe cold event at this time. Holocene abrupt changes appear to be associated with solar radiation inferred by nuclide production rates of Be-10.

3. The 1500 yr-cycle in the percentage curve of a relatively cold element-Salix during the Holocene indicates the teleconnection between regional climate systems. Together with the close relationship of abrupt climate change with the solar radiation mentioned above, this study also indicates the significant influence of solar output. Further modeling experiments are expected to elucidate the relative role of climate forcings for this region.

\section{Acknowledgements}

The authors wish to thank Prof. C. F. Hsieh at the Lifesciences Department of National Taiwan University and Prof. Ge Yu in the Nanjing Institute of Geography and Limnology of the Chinese Academy of Sciences, 
for the discussions of biomization. The senior author also wishes to thank the colleagues of palynology in China for sharing their experience in pollen work.

\section{Appendix A. Supplementary data}

Supplementary data associated with this article can be found, in the online version, at doi:10.1016/j.epsl.2006. 08.002 .

\section{References}

[1] H.E. Wright Jr., J.E. Kutzbach, T. Webb III, W.F. Ruddiman, F.A. Street-Perrott, P.J. Bartlein (Eds.), Global Climates since the Last Glacial Maximum, Univ. Minnesota Press, Minneapolis, 1993, $569 \mathrm{pp}$.

[2] B.A.S. Davis, S. Brewer, A.C. Stevenson, J. Guiot, The temperature of Europe during the Holocene reconstructed from pollen data, Quat. Sci. Rev. 22 (2003) 1701-1716.

[3] Z.S. An, S.C. Porter, J.E. Kutzbach, X.H. Wu, S.M. Wang, X.D. Liu, X.Q. Li, W.J. Zhou, Asynchronous Holocene optimum of the East Asian monsoon, Quat. Sci. Rev. 19 (2000) 743-762.

[4] S.J.A. Jung, G.R. Davis, G.M. Ganssen, D. Kroon, Synchronous Holocene sea surface temperature and rainfall variations in the Asian monsoon system, Quat. Sci. Rev. 23 (2004) 2207-2218.

[5] Y. He, W.H. Theakstone, Z. Zhang, D. Zhang, T. Yao, T. Chen, Y. Shen, H. Pang, Asynchronous Holocene climatic change across China, Quat. Res. 61 (2004) 52-63.

[6] W.J. Zhou, X.F. Yu, A.J.T. Jull, G. Burr, J.Y. Xiao, X.F. Lu, F. Xian, High resolution evidence from southern China of an early Holocene optimal and a mid Holocene dry even around the past 18000 years, Quat. Res. 62 (2004) 39-48.

[7] C.T. Chen, H.C. Lan, J.Y. Lou, Y.C. Chen, The dry Holocene Megathermal in Inner Mongolia, Palaeogeogr. Palaeoclimatol. Palaeoecol. 193 (2003) 181-200.

[8] A.K. Gupta, D.M. Anderson, J.T. Overpeck, Abrupt changes in the Asian southwest monsoon during the Holocene and their links to the North Atlantic ocean, Nature 421 (2003) 354-357.

[9] M. Magny, Holocene climate variability as reflected by midEuropean lake level fluctuations and its probable impact on prehistoric human settlements, Quat. Int. 113 (2004) 65-79.

[10] Y.J. Wang, H. Cheng, R.L. Edwards, Z.S. An, J.Y. Wu, C.C. Shen, J.A. Dorale, A high resolution absolute dated late Pleistocene monsoon record from Hulu Cave, China, Science 294 (2001) 2345-2348.

[11] C.A. Dykoski, R.L. Edwards, H. Cheng, D. Yuan, Y. Cai, M. Zhang, Y. Lin, J. Qing, Z. An, Y. Revenaugh, A high resolution, absolute-dated Holocene and deglacial Asian monsoon record from Dongge Cave, China, Earth Planet. Sci. Lett. 233 (2005) 71-86.

[12] G. Bond, W. Showers, M. Cheeseby, R. Lotti, P. Almasi, P. de Menocal, P. Priore, H. Cullen, I. Hajdas, G. Bonani, A pervasive millennial cycle in north Atlantic Holocene and glacial climates, Science 278 (1997) 1257-1266.

[13] G. Bond, B. Kromer, J. Beer, R. Muscheler, M.N. Evans, W. Showers, S. Hoffmann, R. Lotti-Bond, I. Hajdas, G. Bonani, Persistent solar influence on north Atlantic climate during the Holocene, Science 294 (2001) 2130-2136.

[14] Y.T. Hong, B. Hong, Q.H. Lin, Y. Shibata, M. Hirota, Y.X. Zhu, X.T. Leng, Y. Wang, H. Wang, L. Yi, Inverse phase oscillations between the East Asian and Indian Ocean summer monsoons during the last 12000 years and paleo-El Nino, Earth Planet. Sci. Lett. 231 (2005) 337-346.

[15] D. Fleitmann, S.J. Burns, M. Mudelsee, U. Neff, J. Kramers, A. Mangini, A. Matter, Holocene forcing of the Indian monsoon recorded in a stalagmite from southern Oman, Science 300 (2003) 1737-1739.

[16] D.C. Leuschner, F. Sirocko, Orbital insolation of the Indian monsoon - a motor for 19 global climate changes? Palaeogeogr Palaeoclimatol. Palaeoecol. 197 (2003) 83-95.

[17] B.K. Linsley, S. Dammemmann, Millenial scale dynamics of the Eastern Asian monsoon during the last 200,000 years, Paleoceanography 16 (2001) 1-12.

[18] A.K. Gupta, D.M. Andersont, T. Overpeck, Abrupt changes in the Asian monsoon during the Holocene and their links to the north Atlantic Ocean, Nature 421 (2003) 354-357.

[19] I.C. Prentice, J. Guiot, B. Huntley, D. Jolly, R. Cheddadi, Reconstructing biomes from palaeoecological data: a general method and its application to European pollen data at 0 and $6 \mathrm{ka}$, Clim. Dyn. 12 (12) (1996) 185-194.

[20] G. Yu, P.M. Liew, Z. Li, Surface pollen and vegetation reconstruction from central and northern mountains of Taiwan, Chin. Sci. Bull. 48 (3) (2003) 291-295.

[21] H. Su, Studies on the climate and vegetational types of the natural forest in Taiwan (1): analysis of the variation in climate factors, Q. J. Chin. For. 17 (3) (1984) 1-14.

[22] H. Su, Studies on the climate and vegetational types of the natural forest in Taiwan (II): altitudinal variation in zones in relation to temperature gradient, Q. J. Chin. For. 17 (4) (1984) 57-73.

[23] P.M. Liew, C.M. Kuo, S.Y. Huang, M.H. Tseng, Vegetation change and terrestrial carbon storage in eastern Asia during the last glacial maximum as indicated by a new pollen record from central Taiwan, Glob. Planet. Change 16-17 (1998) 85-94.

[24] C.M. Kuo, P.M. Liew, Vegetation history and climatic fluctuations based on pollen analysis of the Toushe peat bog, central Taiwan since the last glacial maximum, J. Geol. Soc. China 43 (2000) 379-392.

[25] P.M. Liew, S.Y. Huang, C.M. Kuo, Pollen stratigraphy, vegetation and environment of the last glacial and Holocene - a record from Toushe Basin, central Taiwan, Quat. Int. 147 (2006) 16-23.

[26] M. Stuiver, P.J. Reimer, Radiocarbon calibration program CALIB REV4. 4.1, Radiocarbon 35 (1993) 215-230.

[27] H.J. Su, Studies on the climate and vegetation types of the natural forests in Taiwan: (I) Analysis in variation of climate factors, Q. J. Chin. For. 17 (30) (1984) 1-14.

[28] E.C. Grimm, Tilia, Version 2.0 b5, Illinois State Museum, Springfield, 1997.

[29] P.C. Tzedakis, M.R. Frogley, I.T. Lawson, R.C. Preece, I.C. Cacho, L. deAbreu, Ecological thresholds and patterns of millennial-scale climate variability: the response of vegetation in Greece during the last glacial period, Geology 32 (2004) 109-112.

[30] L.G. Thompson, E. Mosley-Thompson, M.E. Davis, J.F. Bolzan, T. Yao, N. Gundestrup, X. Wu, L. Klein, Z. Xie, 100,000 year climate record from Qinghai-Tibetan Plateau ice cores, Science 246 (1989) 474-477.

[31] M. Tsukada, Vegetation in subtropical Formosa during the Pleistocene glaciation and the Holocene, Palaeogeogeogr. Palaeoclimatol. Palaeoecol. 3 (1967) 49-64.

[32] W. Zhou, S. Xie, P.A. Meyers, Y. Zheng, Reconstruction of late glacial and Holocene climate evolution in southern China from geolipids and pollen in the Dingnan peat sequence, Org. Geochem. 36 (2005) 1272-1284. 
[33] Z.-D. Feng, W.G. Wang, L.L. Guo, P. Khosbayar, T. Narantsetseg, A.J.T. Jull, C.B. An, X.Q. Li, H.C. Zhang, Y.Z. Ma, Lacustrine and eolian records of Holocene climate changes in the Mongolian Plateau: preliminary results, Quat. Int. 136 (1) (2005) 25-32.

[34] J. Xiao, T. Nakamura, H. Lu, G. Zhang, Holocene climate changes over the desert/loess transition of north-central China, Earth Planet. Sci. Lett. 197 (2002) 11-18.

[35] K.F. Yu, J.X. Zhao, G.J. Wei, X.R. Cheng, P.X. Wang, Mid-late Holocene monsoon climate retrieved from seasonal $\mathrm{Sr} / \mathrm{Ca}$ and $\delta^{18} \mathrm{O}$ records of Porites lutea corals at Leizhou Peninsula, northern coast of South China Sea, Glob. Planet. Change 47 (2-4) (2005) 301-316.

[36] W. Wu, T. Liu, Possible role of the Holocene event 3 on the collapse of Neolithic cultures around the Central Plain of China, Quat. Int. 117 (2004) 153-166.

[37] N.J. Chung, Studies on the vegetation ecology and the conservation characteristics of Salisien area, central Taiwan. PhD Thesis National Taiwan University (1994) 183 pp.

[38] K.F. Yu, J.X. Zhao, T.S. Liu, G.J. Wei, P.X. Wang, K.D. Collerson, High-frequency winter cooling and reef coral mortality during the Holocene climatic optimum, Earth Planet. Sci. Lett. 224 (1-2) (2004) 143-155.

[39] A.S. Issar, Climate Change during the Holocene and their Impact on Hydrological Systems, Cambridge University Press, Cambridge, $2004143 \mathrm{pp}$.

[40] L.G. Thompson, E. Mosley-Thomson, M.E. Davis, K.A. Henderson, H.H. Brecher, V.S. Zagorodnov, T.A. Mashiotta, P.N. Lin, V.N.
Mikhalenko, D.R. Hardy, J. Beer, Kilimanjaro Ice core records: evidence of Holocene climate change in tropical Africa, Science 298 (2002) 589-593.

[41] Ashish Sarkar, R. Ramesh, B.L.K. Somayajulu, R. Agnihotri, A.J.T. Jull, G.S.A. Burr, High resolution Holocene monsoon record from the eastern Arabian Sea, Earth Planet. Sci. Lett. 177 (2000) 209-218.

[42] C.M. Moy, G.O. Seltzer, D.T. Rodbell, D.M. Anderson, Variability of El Nino/Southern Oscilation activity at millennial timescales during the Holocene epoch, Nature 420 (2002) $162-165$.

[43] C.S Turney, A.P. Kershaw, S.C. Clemens, N. Branch, P.T. Moss, L.K. Fifield, Millenial and orbital variations of El Nino/Southern oscillation and high - latitude climate in the last glacial period, Nature 428 (2004) 306-310.

[44] J.R.M. Allen, W.A. Watts, B. Huntley, Weichselian palynostratigraphy, palaeovegetation and palaeoenvironment; the record from Lago Grande di Monticchio, south Italy, Quat. Int. 73/74 (2000) 91-110.

[45] E. Bard, M. Arnold, B. Hamelin, N. Tisnerat-Laborde, G. Cabioch, Radiocarbon calibration by means of mass spectrometric ${ }^{230} \mathrm{Th} /{ }^{234} \mathrm{U}$ and ${ }^{14} \mathrm{C}$ ages of corals: an updated database including samples from Barbados, Mururoa and Tahita, Radiocarbon 40 ((3) 2) (1998) 1085.

[46] M. Stuiver, P.J. Reimer, Radiocarbon calibration program CALIB REV4.4.1, Radiocarbon 35 (1993) 215-230. 